DRAFT: For published version consult Dialogue.

\title{
Overall and Aquinas on Miracles
}

\section{DAVID K. KOVACS Fordham University}

For nearly three decades Christine Overall has been arguing that the existence of miracles would serve as evidence against the existence of God. ${ }^{1}$ Because she believes miracles would constitute a kind of evil, she believes that if they exist (and she believes that they do not) they would disprove the existence of a benevolent God. ${ }^{2}$ Specifically, she believes they would disprove the possibility of what she calls the "Christian God." As such, her argument is a unique version of the Problem of Evil argument against God's existence. It is unique because most arguments from evil try to show that God cannot exist since if God did exist, and if he were both omnipotent and benevolent, he would prevent evil. ${ }^{4}$ And most counter arguments try to show that God is under no obligation to do so. ${ }^{5}$ But Overall's claim is not that God should be preventing evil. She argues that a miracle is an evil. If there exists a miracle, it is an evil committed by God. This is stronger than the claim that God is unjust in permitting evil.

In this paper, I claim that Overall's argument results from a common conception of the relation between God and creation. This conception, which I will call the God-the-Outsider conception, is held by both some theists and some atheists. God-the-Outsider conceptions

\footnotetext{
${ }^{1}$ Christine Overall, "Miracles as Evidence Against the Existence of God," Southern Journal of Philosophy 23 (1985): 347-353; "Miracles and God: A Reply to Robert A. H. Larmer," Dialogue: Canadian Philosophical Review 36 (1997): 741-752; "Miracles and Larmer," same journal, 42 (2003): 123-135; "Miracles, Evidence, Evil, and God: A Twenty Year Debate," same journal, 45 (2006): 355-366. As is clear from these titles, her primary opponent in these debates has been Robert Larmer, whose objections I will address.

${ }^{2}$ Overall (2006), 356.

${ }^{3}$ Overall (1985), 352. Note especially her concluding sentence: "[l]f I am right [i.e., about miracles counting as evidence against the existence of God], such a being, if it exists, could not have the characteristics we usually attribute to God, and thus could not be the Christian God."

${ }^{4}$ By convention, I use the masculine personal pronoun for God. In doing so, I mean to attribute neither gender (nor even personality) to God.

${ }^{5}$ For just one such defense, see Richard Swinburne's "The Problem of Evil" in Reason and Religion, ed. Stuart C. Brown (Cornell University Press, 1977).

AUTHOR'S DRAFT: To cite, please consult published version in Dialogue: Canadian Philosophical Review
} 
DRAFT: For published version consult Dialogue.

result in an understanding of miracles which leads to the sort of argument Overall puts forth. I will also show that this understanding of miracles, as well as the God-the-Outsider conception, has not been the unanimous view of all theists. It was not the view of Thomas Aquinas. If Aquinas's conception of the relation between God and creation is correct, then there is no reason to agree with Overall that miracles are a kind of evil. But then this means that some theists today have an incorrect understanding of the relation between God and creation.

\section{Overall's Argument}

Overall begins her argument by offering a definition of miracle that is neutral with respect to the existence of God. She does this because if God is an essential part of the definition of miracle, then the positive identification of an event as a miracle necessarily implies God's existence, but only circularly. Any concept of miracle which includes God in the definition, Overall claims, "encourages us to focus on the problem of the identification of a particular event as a miracle, rather than on the exploration of the connection between a certain kind of event, called a miracle, and God." ${ }^{\prime \prime}$ In other words, rather than focusing on whether some particular event is a miracle, we ought to focus on what miracles (if they occur) tell us about God, if anything.

With this in mind, Overall proposes a new definition of miracle. A miracle, she writes, is any event that is a violation of nature or permanently inexplicable. ${ }^{7}$ It isn't clear if she means by "or" to suggest a disjunction, such that some miracles are just violations of laws of nature, some are just permanently inexplicable events, and perhaps some are both, or

\footnotetext{
${ }^{6}$ Overall (1985), 348.

${ }^{7}$ lbid.
}

AUTHOR'S DRAFT: To cite, please consult published version in Dialogue: Canadian Philosophical Review 
DRAFT: For published version consult Dialogue.

if she means to say the two classes are co-extensive: Every conceivable violation of nature is inexplicable and vice versa. If she means the latter, then she offers no argument for it and it is not obvious that the two classes are co-extensive. If God makes a man levitate then someone might call this a violation of nature's laws but it is certainly explainable: God is able to do that sort of thing. Likewise, just because an event is permanently inexplicable does not mean it violates any law: It may be that there are some laws of nature permanently unknowable by us, or there could be an event that, by chance, we never discover a law capable of serving as an explanation. I believe that Overall's arguments for why miracles would serve as evidence against the existence of God are strongest if we take her to mean miracles are violations of laws of nature that can never be explained unless they are attributed ad hoc to divine action. That such violations could only be produced by God is, apparently, accidental to the definition.

The bottom line, so to speak, of Overall's argument is that the claim that God exists is inconsistent with the claim that miracles exist. Thus we find her writing that "[l]f one knew that God exists, then probably nothing could be identified as a miracle, and conversely, if event $x$ could be identified as a miracle, one would have good reason to believe God does not exist."8 And her reason for this conclusion has to do with her claim that miracles amount to an evil: "If they occur," Overall says, "miracles increase the amount of evil in the world." She goes on to say that miracles constitute three kinds of evil: Ontic evil, cognitive evil, and moral evil. ${ }^{9}$ I will briefly say what she means by each of these three kinds of evil:

1. Miracles are an ontic evil because if God is omniscient and if God makes the laws of

\footnotetext{
${ }^{8}$ Overall (1985), 349.

${ }^{9}$ Overall (2009), 356.
}

AUTHOR'S DRAFT: To cite, please consult published version in Dialogue: Canadian Philosophical Review 
DRAFT: For published version consult Dialogue.

the universe, he should not have to violate them. Either God wasn't able to foresee the problems his laws would create and thus has to violate his laws to address certain problems, or God wasn't able to create a regular universe able to avoid those problems in the first place. If the former, God is not omniscient (and thus not God), in the latter God is not omnipotent (and thus not God).

2. Miracles are a cognitive evil because they seriously jeopardize our ability to understand the world. Understanding presupposes conformity and regularity. When our predictive models fail us we scrap some of our beliefs to search for a better understanding of the universe. But if God can change the rules any time he desires, our ability to really understand will never come to fullness. Moreover, miracles would "appeal to our cognitive weaknesses: fear, ignorance, suggestibility and awe of the unknown."10

3. Miracles are a moral evil. They show God to be capricious. Overall especially likes to think of the Christian miracle of the wedding at Cana. ${ }^{11}$ The story goes that Jesus was at a wedding, they ran out of wine, and so Jesus miraculously turned water into wine. Overall asks what sort of God performs miracles like this while so many people are starving? And, if it is the case that God does periodically help a starving person by means of a miracle (which, Christians believe, Jesus also did), then why only some people and not others? If God performs miracles, then God is apparently very unfair for not performing miracles for someone else.

Note that Overall's understanding of how God would perform a miracle requires a specific understanding of the relation between God and creation. Implicit in Overall's account, when God performs a miracle, God is intervening. I call this account, or any

\footnotetext{
${ }^{10}$ Ibid.

${ }^{11}$ Ibid. 358-360.
}

AUTHOR'S DRAFT: To cite, please consult published version in Dialogue: Canadian Philosophical Review 
DRAFT: For published version consult Dialogue.

account which cashes out miracles in terms of intervention, the God-the-Outsider conception. On the one side you have creation. It runs according to rules and laws. It includes things we like but also many things we don't like. In general, it is like a machine that runs nonstop and we who live in the machine are doing our best to understand how it works.

On the other side you have God, who is outside the machine, considerably stronger than the machine, and able to do to the machine anything he wants. God alone is able to tinker with the machine. Miracles come about whenever God changes one of the normal, predictable operations of the machine. He switches out parts for different parts or interrupts some operation. In line with what I said above, Overall seems to think that this means miracles imply that 1) God didn't make a very good machine to begin with; 2) Our ability from inside the machine to understand how it works is compromised; and 3) God is morally negligent for only tinkering with some parts of the machine and not others.

Overall is not the only person who conceives of the relation between a supposed God and the world in this way. ${ }^{12}$ Such a conception is implicit in any notion of miracle that speaks of miracles as interventions. This is operative in the works of theists like Richard Swinburne, who writes that miracles are "a violation of a law of Nature by a god, that is, a very powerful rational being who is not a material object (viz., is invisible and intangible)." ${ }^{13}$ Robert Larmer, Overall's most vocal critic, has a definition of miracles which involves a transcendent being doing things that nature can't. He says he thus understands a miracle as just God

\footnotetext{
${ }^{12}$ In fact, she cites Douglas Odegard, lan Walker, and David Basinger as philosophers who define miracles as interventions and who, I claim, would therefore conceive of God as an outsider. Overall (1985): 347-48.

${ }^{13}$ Richard Swinburne, "Miracles," Philosophical Quarterly 18 (1968): 320. I should add that Swinburne does in fact understand God as creator; my reason for citing him is merely to illustrate that even one of the most important contemporary philosophers of religion uses the language of "violating laws of nature," language that I hope to show is problematic, at least for thinkers like Aquinas.

AUTHOR'S DRAFT: To cite, please consult published version in Dialogue: Canadian Philosophical Review
} 
DRAFT: For published version consult Dialogue.

"overriding" nature, not violating it. ${ }^{14}$ Even here, though, the impression is that God is outside of nature, periodically able to override its laws.

\section{Aquinas and Miracles}

But is the God-the-Outsider conception the only way traditional theism can approach the relation between God and creation? And, if not, how does that effect the understanding of miracles as interventions? The notion of God as an outsider seems to be closely related to the rise of deism. It is remarkable that many theistic definitions of miracle resemble that of David Hume, "a transgression of a law of nature by a particular volition of the Deity." 15

This is not Aquinas's thought. For Aquinas, to call God creator is also to call God sustainer. Everything that exists does so because God is willing it to exist for as long as it exists. ${ }^{16}$ It is not the case, for Aquinas, that God made the universe to come to exist at some point a long time ago and then leaves it to exist on its own; God did not make a machine and then set it to do what it does. God is what is keeping every part of the universe existing and moving at any given time. Thus, Aquinas writes:

God is in all things ... as an agent is present to that upon which it works. For an agent must be joined to that wherein it acts immediately and touch it by its power... Now since God is very being by His own essence, created being must be His proper effect; as to ignite is the proper effect of fire. Now God causes this effect in things not only

\footnotetext{
${ }^{14}$ Robert Larmer, "Miracles and Overall: An Apology for Atheism?" Dialogue: Canadian Philosophical Review 43 (2004): 555-556.

${ }^{15}$ David Hume, An Enquiry Concerning Human Understanding, ed. Tom L. Beauchamp (Oxford: Oxford University Press, 2000), 87. Hume was not a deist, but his understanding of God and miracles certainly would have been influenced by the deism that was popular shortly before his era.

${ }^{16}$ See Summa Theologiae I, 14, 8; I, 19, 4; and I, 20, 2.
}

AUTHOR'S DRAFT: To cite, please consult published version in Dialogue: Canadian Philosophical Review 
DRAFT: For published version consult Dialogue.

when they first begin to be, but as long as they are preserved in being; as light is caused in the air by the sun as long as the air remains illuminated. Therefore as long as a thing has being, God must be present to it. ${ }^{17}$

So, on Aquinas's view, to say that God is transcendent means that God is not created and is not like anything that is created. ${ }^{18}$ It is not to say that God is just nowhere to be found in creation. Quite the contrary: God is to be found in everything in creation. For this reason, it makes no sense to speak of God as "intervening." Thinking along these lines, Herbert McCabe puts it thus:

[I]t is clear that God cannot interfere in the universe, not because he has not the power but because, so to speak, he has too much; to interfere you have to be an alternative to, or alongside, what you are interfering with. If God is the cause of everything, there is nothing that he is alongside. Obviously, God makes no difference to the universe. I mean by this that we do not appeal specifically to God to explain why the universe is this way rather than that, for this we need only to appeal to explanations within the universe . . . What God accounts for is that the universe is there instead of nothing. ${ }^{19}$

The idea here, as it is in Aquinas, is that to interfere or intervene, one has to be, in some sense, alongside what one is interfering with. One cannot interfere with a state

\footnotetext{
${ }^{17}$ Summa Theologiae I, 8, $1 \mathrm{co}$. I quote from the 1920 English Dominican translation. Italicization mine.

${ }^{18}$ For example, in $S T I, 13,7$, when Aquinas says that God is entirely outside the order of creatures, he clarifies that what he means is that creatures are ordered toward God and not the other way around.

${ }^{19}$ Herbert McCabe, "Creation," first published in New Blackfriars 61 (1980). Here quoted from Brian Davies (ed.), Philosophy of Religion: A Guide and Anthology (Oxford: Oxford University Press, 2000), 199. Italics in original. AUTHOR'S DRAFT: To cite, please consult published version in Dialogue: Canadian Philosophical Review
} 
DRAFT: For published version consult Dialogue.

of affairs that exists only because one is sustaining and creating that state of affairs. God is already too intimately involved with everything that is happening to interfere or intervene. $^{20}$

So if it is not the case that God is an outsider who is observing what happens inside of creation, how does Aquinas understand miracles? Aquinas's thought on miracles is as follows: God is the cause of all that is and, by divine providence, is directing all things that happen in creation. ${ }^{21} \mathrm{He}$ allows this to happen in two ways. The first is when he directs things to act according to their created nature. ${ }^{22}$ Thus, created things act on each other the way they do because God has given the things in nature the causal powers that they have. But God also sometimes acts in the world with no use of created powers at all. This second way of acting is what Aquinas takes a miracle to be. ${ }^{23}$ Yet God is as much at work in the regular events of nature as he is in the miraculous. ${ }^{24}$ A miracle is just God acting in the absence of a created power. As McCabe, again, succinctly puts it: "A miracle is not God intervening in the world-God is always acting in the world-a miracle is when only God is acting in the world."25

\section{Are Miracles Incompatible with the Existence of God?}

Where does this leave us with regard to Overall's argument? Her claim is that if a miracle happens, it shows God to be evil, and thus shows that God does not exist. But why would a

\footnotetext{
${ }^{20}$ None of this means that Aquinas is an occasionalist. God acts concurrently with the secondary causes that he creates. For details, see Alfred J. Freddoso, "God's General Concurrence with Secondary Causes: Pitfalls and Prospects," American Catholic Philosophical Quarterly 68 (1994): 131-156.

${ }^{21}$ De Veritate V, 2 and 4.

${ }^{22}$ Summa Contra Gentiles III, 67.

${ }^{23}$ Summa Contra Gentiles III, 101.

${ }^{24}$ Note that this is why Aquinas says that angels cannot perform miracles: Anything an angel might be able to do, it is able to do only because God created it with the power to do so. Summa Theologiae I, 110, 4.

${ }^{25}$ Herbert McCabe, "God, Evil, and Divine Responsibility," in Brian Davies (ed.), Philosophy of Religion: A Guide and Anthology (Oxford: Oxford University Press, 2000): 620. Italics in original.

AUTHOR'S DRAFT: To cite, please consult published version in Dialogue: Canadian Philosophical Review
} 
DRAFT: For published version consult Dialogue.

miracle show God to be evil?

The first reason she gives, the ontic reason, is that God should have made the laws of nature sufficient to do whatever God does by miracle. But where does that obligation come from? On Aquinas's view, the laws of nature inhere in things even now only because God is willing them to. And God is free to will whatever things he wants. If clouds are able to produce rain it is only because God wills that clouds be the sorts of things that can produce rain. It is no different, thinks Aquinas, from God willing that some water become wine or that some man levitate. Everything that happens does so because God wills it. There is never an intervention (or an "overriding" as Larmer puts it). There is just God doing things, either with or without the actions of created causes. There is no reason to insist that God only act by means of created causes. So, contrary to Overall, miracles pose a threat to neither God's omnipotence nor his omniscience.

Overall's second claim is that miracles would render the created order less knowable. Here I think Overall believes that knowledge must be identical to predictive power. But other models are possible. Knowledge may be knowledge of the essence and natural powers of a thing. I can know that fire has the ability to make things hot even if there is an instance where it does not. Fire put to wood should heat and ignite the wood. But God could will that the fire be next to the wood while also willing that the wood remain cool and unburned. This takes nothing away from what I know the power of fire to be; it means only that I can also know God to be more powerful than fire. Furthermore, given the rarity of miracles, it seems the workings of nature are at least consistent enough to be usefully predicted. Identifying an event as a miracle in any sense of the word-that is, as an event brought about by directly God without the use of a natural cause, or as an event that is permanently inexplicable-is only possible if we accept that the normal operations of things are usually consistent. AUTHOR'S DRAFT: To cite, please consult published version in Dialogue: Canadian Philosophical Review 
DRAFT: For published version consult Dialogue.

In other words, if we acknowledge the existence of a God who is always at work in the universe, we need not abandon science or predictive models of the world. Instead, we need only to admit that when confronted with an event that is permanently inexplicable with respect to science and predictive models, God is at work without concurrent natural causes.

Lastly, miracles do not make God capricious and unfair, as Overall claims. It may be true that we do not know why God performs a miracle in one event and not in another. But is God ever obligated to perform a miracle? Certainly not, thinks Aquinas. ${ }^{26}$ Rather, every act of God, whether with or without created causes, is directed toward the good of the universe as it ultimately comes to rest in him.

Overall's arguments show one thing: That if our view of the relation between God and creation is one that treats God as an outsider, then theists have a serious difficulty explaining how miracles will be possible given the benevolence of God. Overall's conclusion, that "the Christian God" is not one who would bring about miracles, is likely not to sit well with those who believe in such a God. However, theists have an alternative conception of the relation between God and creation available to them. Here I hope to have shown how a different (yet traditional) conception, where God is the sustainer and director of everything that is and that happens, avoids the problems Overall raises.

\footnotetext{
${ }^{26}$ It's been written elsewhere that, for Aquinas, there was not and could not have been what we call "the problem of evil." For a book length study of that issue, see Brian Davies, Aquinas on God and Evil (Oxford: Oxford University Press, 2011). For a short and very accessible explanation for how Aquinas's theology would account for evil, see Herbert McCabe, "Evil," in God Matters (London and New York: Continuum, 2005), 2538.

AUTHOR'S DRAFT: To cite, please consult published version in Dialogue: Canadian Philosophical Review
} 